\title{
Effect of Prepartum Rumen Protected Choline Supplementation on Postpartum Nutrient Intake, Digestibility and Body Weight Changes in Crossbred Dairy Cows
}

\author{
Devendra Kumar Gupta ${ }^{1}$, R.S. Grewal ${ }^{1 *}$, Simarjeet Kaur ${ }^{2}$ and J.S. Lamba ${ }^{1}$ \\ ${ }^{1}$ Department of Animal Nutrition, GADVASU, Ludhiana, India \\ ${ }^{2}$ Directorate of Livestock Farms, GADVASU, Ludhiana, India \\ *Corresponding author
}

\section{A B S T R A C T}

In the present study 24 high milk yielding crossbred cows were selected based upon their parity, lactation milk yield and body condition score. These cows were divided into four groups keeping 6 cows in each group. Cows in Group 1 and group 2 were fed with ration containing high NEL having $1.50 \mathrm{Mcal} / \mathrm{kg}$ and designated as high energy control (HEC) and high energy choline (HECh). Cows in Group 3 and Group 4 were fed with ration

\section{Keywords}

Rumen protected choline, Crossbred cows, Body weight changes

\section{Article Info}

\section{Accepted:}

10 April 2019

Available Online:

10 May 2019 containing low NEL having $1.26 \mathrm{Mcal} / \mathrm{kg}$ and designated as low energy control (LEC) and low energy choline (LECh). Cows of HECh and LECh were supplemented with Rumen Protected Choline (RPC) at the rate of $30 \mathrm{~g} /$ day. The feeding of the cows was started 21 days before expected date of calving and continued upto 10 days post calving. Body weight and BCS were recorded up to 90 days post calving. Significant difference for average DMI was found between low and high energy groups during pre calving period and average DMI was significantly lower for cows fed on low energy ration. For high energy ration difference was found between HEC and HECh group in average DMI which was significantly lower in HECh group than HEC $(\mathrm{P}<0.05)$. DMI after calving increased consistently upto 10 days. There was significant difference $(\mathrm{P}<0.05)$ in DMI for different groups after calving and it was significantly higher in groups fed on high energy ration than groups fed on low energy ration. DMI was significantly higher $(\mathrm{P}<0.05)$ in the LECh group than LEC group. Significant interaction $(\mathrm{P}<0.05)$ was found between number of days post calving and different groups for Dry Matter Intake. For different groups irrespective of the number of days around calving, no significant difference was there in the values of BCS. These results suggested that change in BCS is not affected by RPC supplementation. Significant interaction $(\mathrm{P}<.05)$ was found between number of days and different groups for BCS during post calving period. Body weight and BCS loss was less in RPC supplemented groups than control groups so RPC supplementation improves post calving body condition of cows.

\section{Introduction}

The dairy cattle experiences negative energy balance prior to calving. This occurs because of the reduction in the dry matter intake (DMI) and the increasing nutrient demand by the growing foetus, primarily the former. The negative energy balance and the hormonal 
changes resulted in higher plasma free fatty acid mobilization from the adipose tissue and glycogen from liver (Grummer, 1995). In dairy cows, dry matter consumption during this period decline by $30 \%$ due to the increased levels of plasma non esterified fatty acids (NEFA) concentration in the blood (Bertics et al., 1992).

Hepatic capacities for fatty acid oxidation and export as very low density lipoproteins (VLDL) are low in ruminants (Grummer, 1993); therefore, excessive uptake of NEFA by the liver can lead to the development of hepatic lipidosis (fatty liver caused by the accumulation of triglycerides within the liver parenchyma). Phosphatidylcholine is required for the secretion of very low density lipoprotein (VLDL) from liver. Thus supplying choline directly may enhance synthesis of phosphatidylcholine and increase VLDL synthesis.Feedstuffs for dairy cattle contain free choline and phosphatidylcholine but as the content of these compounds in plants is relatively small and their ruminal degradation is extensive (Sharma and Erdman, 1989) so their intestinal supply is not enough to meet tissue requirements. The microbial populations in the rumen quickly degrade dietary choline; therefore, the only practical means of increasing choline to the periparturient dairy cows is to feed it in a rumen-protected form (Atkins et al., 1988). The present study was planned to study the effect of high energy levels with or without rumen protected choline before calving on the post calving performance of crossbred cows.

\section{Materials and Methods}

Twenty four late pregnant high genetic potential crossbred cows were selected based upon their parity, lactation milk yield and body condition score. All these cows were kept under loose housing system in individual pens. These cows were divided into four groups of six cows in each group. Cows in Group 1 and group 2 were fed with ration containing high energy having $\mathrm{NE}_{\mathrm{L}} 1.50$ $\mathrm{Mcal} / \mathrm{kg}$ and designated as high energy control (HEC) and high energy choline (HECh). Cows in Group 3 and Group 4 were fed with ration containing low $\mathrm{NE}_{\mathrm{L}}$ having $1.26 \mathrm{Mcal} / \mathrm{kg}$ and designated as low energy control (LEC) and low energy choline (LECh). Cows of HECh and LECh were supplemented with Rumen Protected Choline (RPC) at the rate of $30 \mathrm{~g} /$ day. All the cows were fed twice a day and water was freely available throughout the day.

The feeding of the cows was started 21 days before expected date of parturition of the cows and continued upto 10 days post calving. After 10 days post calving all the cows were given same lactation ration and data was recorded up to 90 days post calving during which period all animals were given same ration with concentrate to green ration of 60:40. The chemical analysis of feed, feaces and residue was done according to AOAC (2000). Composition of the concentrate fed to the cows during in vivo experiment is given in table 1. This concentrate mixture was supplied with seasonal green fodder in a ratio of 50:50 on DM basis for concentrate: green fodder for cows fed on high energy ration. For low energy ration straw was also mixed in TMR in a ratio of 40:20:40 for concentrate: green fodder: straw on DM basis.

Percentage of various nutrients (CP, EE, NDF, ADF, Ash and Cellulose) was estimated twice a week in these samples. Body Condition Scores (BCS) of cows were noted according to body condition scoring chart adapted from Edmonson et al., (1989).After 10 days of calving all cows were fed with same lactation ration in which concentrate mixture was supplied along with oat silage or seasonal green fodders. The digestibility of each ration 
was determined by marker method using $\mathrm{Cr}_{2} \mathrm{O}_{3}$ as a marker (Hill and Anderson 1958).

\section{Results and Discussion}

Dry matter intake (DMI) during pre calving period was significantly $(\mathrm{P}<0.05)$ decreased in all the groups as animal comes near to calving (Table 2). Similar results were reported by Grummer (1995). Though the decrease was less in treatment groups than their respective control groups. Significant difference for average DMI was found between low and high energy groups during pre calving period and average DMI was significantly lower for animals fed on low energy ration.

These results could be correlated to the fact that low energy ration has more NDF\% which limits DMI by rumen fill process suggested by Mertens (1994), Dado and Allen (1995) and Allen (2000). For high energy ration difference was found between control and treatment group in average DMI which was significantly lower in treatment group than control $(\mathrm{P}<0.05)$. This result is in contrast with results obtained by many scientists (Piepen brink and Overton 2003, Guretzky et al., 2006) who suggested no effect of RPC on DMI during pre or post partum period. Interaction b/w no. of days before calving and different groups was found non significant for DMI before calving which shows that decrease in DMI near calving is independent of RPC supplementation and energy concentration of the ration.

During pre partum period there was significant difference $(\mathrm{P}<0.05)$ in nutrient intake among the four groups. $\mathrm{OM}$ intake, $\mathrm{CP}$ intake and $\mathrm{EE}$ intake were found significantly higher $(\mathrm{P}<0.05)$ in groups fed with high dietary energy concentration than groups fed with low energy concentration in their ration (Table 3). These results may be attributed to higher DMI in the groups fed on high energy ration than low energy ration. Between two groups fed on ration having high dietary energy concentration, intake of OM, NDF, $\mathrm{ADF}$, Cellulose and $\mathrm{OM}$ was found significantly less $(\mathrm{P}<0.05)$ in treatment group than control group. Two groups fed on low dietary energy concentration were significantly different $(\mathrm{P}<0.05)$ in intake of $\mathrm{CP}, \mathrm{ADF}$ and Cellulose which were higher in control group then treatment group.

During post calving period, between the two groups fed on same high energy concentration ration, no significant difference was there for intake of any of the above measured parameters between HEC and HECh groups (Table 4). However non significant increase $(\mathrm{P}>0.05)$ was there in the nutrient intake for HECh group than HEC group. But for the two groups fed on same low energy ration, there was significant increase in the intake of almost all the above measured nutrients for LECh group than LEC group $(\mathrm{P}<0.05)$. These results were in favour of the results obtained in some previous studies (Oelrichs et al., 2004, Chung et al 2005, Lima et al., 2007) in which increase in DMI with RPC supplementation was observed. These results showed that RPC supplementation at $75 \mathrm{ppm}$ level increased nutrient intake for cows fed on a low dietary energy concentration during post calving period.

During post calving period DMI, along with almost all the nutrients measured above, was significant higher $(\mathrm{P}<0.05)$ in the groups fed on high energy ration than low energy ration (Table 5). Reason may be same as explained for difference in DMI during pre calving period (Mertens, 1994; Dado and Allen, 1995 and Allen, 2000). Between the two groups, fed on same high energy concentration ration, no significant difference was there for intake of any of the above measured parameters between control and treatment groups. 
However non significant increase was there in the nutrient intake for treatment group than control group $(\mathrm{P}>0.05)$. But for the two groups fed on same low energy concentration ration, there was significant increase $(\mathrm{P}<0.05)$ in the intake of almost all the above measured nutrients for treatment group than control group. These results were in favour of the results obtained in some previous studies (Oelrichs et al., 2004; Chung et al., 2005; Lima et al., 2007) in which increase in DMI with RPC supplementation was told. With these results we can draw the conclusion that RPC supplementation triggers nutrient intake to a more extent for animals fed on a low dietary energy concentration during post calving period.

Comparison among different groups for DMI before and after calving shows that DMI is significantly higher $(\mathrm{P}<0.05)$ post calving than pre calving at 5\% level of significance for the groups supplemented with RPC which suggest early recovery of RPC supplemented animals from physiological mechanisms that decrease DMI during transition period (Table 6). These mechanisms may be hormonal changes, space occupying effect of pregnant uterus or rumen fill mechanism as suggested by Grummer (1995). However DMI was significantly lower $(\mathrm{P}<0.05)$ post calving than pre calving for control animals fed on low energy concentration ration and non significantly less $(\mathrm{P}>0.05)$ post calving than precalving for control animals fed on high energy ration.

These results are normal for dairy cows as DMI for post calving period in this study was noted only upto 10 days. This comparison also concludes more stimulating effect of RPC supplementation on DMI Post calving for groups fed on low energy concentration ration than groups fed on high energy concentration ration.
No significant difference was there for the digestibility of various nutrients among various groups at 5\% level of significance (Table 7). However non significant increase was there in the digestibility of all the nutrients in treatment group over control group for both low and high energy fed groups. These results show that supplementation of RPC with high and low energy containing diets does not significantly affect digestibility of various nutrients during pre calving stage.

During post calving stage digestibility of organic matter (OM), $\mathrm{CP}, \mathrm{NDF}$ and $\mathrm{ADF}$ in treatment group was significantly higher $(\mathrm{P}<.05)$ than control group for groups fed on high energy ration (Table 8). Though digestibility of DM, EE and cellulose was also increased in this treatment group but these results were non significant at 5\% level of significance $(\mathrm{P}>0.05)$. For groups of dairy cows fed on low energy ration there was significant increase in the digestibility of $\mathrm{NDF}$ and $\mathrm{ADF}$ in treatment group over control group $(\mathrm{P}<0.05)$ though non significant increase was there in the digestibility of all other nutrients also. These results are in agreement to the results obtained by Mohsen et al., (2011). These results indicate that nutrient utilization (digestibility) during post calving period is highly improved for animals supplemented with RPC at the rate of $30 \mathrm{~g}$ per day in their feed during transition period. This improvement in nutrient utilization was true for animals fed on high or low energy containing ration.

Loss in body weight was almost similar in all the groups before calving but after calving it was less in treatment groups for both high and low energy ration (Table 9). From 1 to 2 months after parturition body weight loss was significantly lower in treatment group than control for groups fed on high energy ration $(\mathrm{P}<.05)$. It was in contradiction to the results 
found by Erdman and Sharma (1991) who found no significant change in body weight loss between control and treatment group. With these results we can conclude that RPC supplementation helps in improving body condition of animal post calving by preventing loss of too much body weight after calving.

Table.1 Composition of concentrate mixture fed during in vivo trial

\begin{tabular}{|l|l|}
\hline Ingredients & Parts of ration (\%) \\
\hline Maize & 28 \\
\hline Mustard cake & 14 \\
\hline Rice bran & 7 \\
\hline DORB & 27 \\
\hline Wheat bran & 6 \\
\hline Soybean & 5 \\
\hline Full Fat Soya & 2 \\
\hline Cottonseed Meal & 5 \\
\hline Guar Kurma & 3 \\
\hline Mineral Mixture & 2 \\
\hline Common Salt & 1 \\
\hline Biotin & 0.02 \\
\hline Toxin binder & 0.1 \\
\hline Vit E & 0.1 \\
\hline yeast & 0.1 \\
\hline
\end{tabular}

Table.2 DMI (kg/d) during pre partum period for different groups

\begin{tabular}{|l|l|l|l|l|l|}
\hline Days & HEC & HECh & LEC & LECh & Average \\
\hline $\mathbf{0}$ & 4.62 & 5.37 & 3.92 & 4.45 & $4.59^{\mathrm{a}}$ \\
\hline $\mathbf{- 3}$ & 7.97 & 6.83 & 5.15 & 5.75 & $6.43^{\mathrm{b}}$ \\
\hline $\mathbf{- 7}$ & 9.88 & 7.6 & 6.65 & 6.61 & $7.69^{\mathrm{c}}$ \\
\hline $\mathbf{- 1 4}$ & 9.67 & 8.57 & 8.16 & 7.04 & $8.36^{\mathrm{cd}}$ \\
\hline $\mathbf{- 2 1}$ & 9.85 & 9.35 & 8.32 & 7.53 & $8.76^{\mathrm{d}}$ \\
\hline Average & $8.40^{\mathrm{c}}$ & $7.51^{\mathrm{b}}$ & $6.46^{\mathrm{a}}$ & $6.28^{\mathrm{a}}$ & Days $\times$ Groups $=$ Non significant $^{\mathrm{a}}$ \\
\hline
\end{tabular}

Different superscripts in row vary significantly at $5 \%$ level of significance

Table.3 Average nutrient intake $(\mathrm{kg} / \mathrm{d})$ during prepartum stage for different groups

\begin{tabular}{|l|l|l|l|l|l|}
\hline Parameter & HEC & HECh & LEC & LECh & SEM \\
\hline DM intake & $8.40^{\mathrm{c}}$ & $7.51^{\mathrm{b}}$ & $6.46^{\mathrm{a}}$ & $6.28^{\mathrm{a}}$ & 0.08 \\
\hline CP intake & $1.16^{\mathrm{c}}$ & $1.06^{\mathrm{c}}$ & $0.94^{\mathrm{b}}$ & $0.78^{\mathrm{a}}$ & 0.02 \\
\hline EE intake & $0.30^{\mathrm{c}}$ & $0.28^{\mathrm{bc}}$ & $0.25^{\mathrm{ab}}$ & $0.21^{\mathrm{a}}$ & 0.007 \\
\hline NDF intake & $4.52^{\mathrm{b}}$ & $3.89^{\mathrm{a}}$ & $3.82^{\mathrm{a}}$ & $3.74^{\mathrm{a}}$ & 0.05 \\
\hline ADF intake & $2.72^{\mathrm{b}}$ & $2.23^{\mathrm{a}}$ & $2.77^{\mathrm{b}}$ & $2.33^{\mathrm{a}}$ & 0.04 \\
\hline Cellulose & $1.54^{\mathrm{b}}$ & $1.22^{\mathrm{a}}$ & $1.99^{\mathrm{c}}$ & $1.31^{\mathrm{a}}$ & 0.03 \\
\hline OM intake & $7.44^{\mathrm{c}}$ & $6.78^{\mathrm{b}}$ & $5.54^{\mathrm{a}}$ & $5.37^{\mathrm{a}}$ & 0.08 \\
\hline
\end{tabular}

Different superscripts in row vary significantly at $5 \%$ level of significance 
Table.4 DMI (kg/d) during post partum period for different groups

\begin{tabular}{|l|l|l|l|l|l|}
\hline No. of days & HEC & HECh & LEC & LECh & Average \\
\hline $\mathbf{1}$ & $5.32 \pm 0.24$ & $6.41 \pm 0.29$ & $4.35 \pm 0.45$ & $5.10 \pm 0.38$ & $5.45 \pm 0.43^{\mathrm{a}}$ \\
\hline $\mathbf{3}$ & $7.48 \pm 0.22$ & $7.56 \pm 0.32$ & $5.38 \pm 0.37$ & $5.82 \pm 0.19$ & $6.71 \pm 0.56^{\mathrm{b}}$ \\
\hline $\mathbf{5}$ & $8.60 \pm 0.27$ & $8.44 \pm 0.38$ & $6.38 \pm 0.25$ & $6.78 \pm 0.32$ & $7.69 \pm 0.57^{\mathrm{c}}$ \\
\hline $\mathbf{7}$ & $9.19 \pm 0.33$ & $9.10 \pm 0.42$ & $6.88 \pm 0.32$ & $7.90 \pm 0.28$ & $8.41 \pm 0.55^{\mathrm{d}}$ \\
\hline $\mathbf{1 0}$ & $9.56 \pm 0.37$ & $9.73 \pm 0.26$ & $7.45 \pm 0.41$ & $9.16 \pm 0.31$ & $9.1 \pm 0.52^{\mathrm{e}}$ \\
\hline Average & $8.03 \pm 0.76^{\mathrm{c}}$ & $8.25 \pm 0.58^{\mathrm{c}}$ & $6.09 \pm 0.55^{\mathrm{a}}$ & $6.95 \pm 0.73^{\mathrm{b}}$ & $\begin{array}{l}\text { Day } \times \text { Group }= \\
\text { significant }(\mathrm{p}<0.05)\end{array}$ \\
\hline
\end{tabular}

Different superscripts in row vary significantly at 5\% level of significance

Table.5 Average nutrient intake $(\mathrm{kg} / \mathrm{d})$ during postpartum stage for different groups

\begin{tabular}{|l|l|l|l|l|l|}
\hline Parameter & HEC & HECh & LEC & LECh & SEM \\
\hline DM intake & $7.89^{\mathrm{c}}$ & $8.14^{\mathrm{c}}$ & $5.99^{\mathrm{a}}$ & $6.87^{\mathrm{b}}$ & 0.11 \\
\hline CP intake & $1.05^{\mathrm{c}}$ & $1.05^{\mathrm{c}}$ & $0.732^{\mathrm{a}}$ & $0.852^{\mathrm{b}}$ & 0.017 \\
\hline EE intake & $0.299^{\mathrm{c}}$ & $0.317^{\mathrm{c}}$ & $0.204^{\mathrm{a}}$ & $0.238^{\mathrm{b}}$ & 0.005 \\
\hline NDF intake & $4.14^{\mathrm{b}}$ & $4.50^{\mathrm{b}}$ & $3.46^{\mathrm{a}}$ & $4.06^{\mathrm{b}}$ & 0.073 \\
\hline ADF intake & $2.51^{\mathrm{ab}}$ & $2.75^{\mathrm{b}}$ & $2.22^{\mathrm{a}}$ & $2.61^{\mathrm{b}}$ & 0.046 \\
\hline Cellulose & $1.39^{\mathrm{ab}}$ & $1.5^{\mathrm{b}}$ & $1.25^{\mathrm{a}}$ & $1.46^{\mathrm{b}}$ & 0.026 \\
\hline OM intake & $6.93^{\mathrm{bc}}$ & $7.52^{\mathrm{c}}$ & $5.41^{\mathrm{a}}$ & $6.32^{\mathrm{b}}$ & 0.118 \\
\hline
\end{tabular}

Different superscripts in row vary significantly at $5 \%$ level of significance

Table.6 Comparison of pre partum and post partum DMI

\begin{tabular}{|l|l|l|}
\hline Treatment & Prepartum & Postpartum \\
\hline HEC & $8.40^{\mathrm{c}}$ & $7.89^{\mathrm{c}}$ \\
\hline HECh & $7.51^{\mathrm{b}}$ & $8.14^{\mathrm{c}}$ \\
\hline LEC & $6.46^{\mathrm{a}}$ & $5.99^{\mathrm{a}}$ \\
\hline LECh & $6.28^{\mathrm{a}}$ & $6.87^{\mathrm{b}}$ \\
\hline SEM & 0.077 & 0.11 \\
\hline
\end{tabular}

Different superscripts in row vary significantly at $5 \%$ level of significance

Table.7 Digestibility (\%) of various nutrients pre calving for different groups

\begin{tabular}{|l|l|l|l|l|}
\hline Nutrient & HEC & HECh & LEC & LECh \\
\hline DM & $52.000 \pm 0.577$ & $57.33 \pm 0.333$ & $50.00 \pm 4.726$ & $50.67 \pm 3.564$ \\
\hline OM & $53.000 \pm 1.00$ & $59.67 \pm 0.882$ & $50.00 \pm 3.00$ & $50.67 \pm 3.712$ \\
\hline CP & $54.333 \pm 0.333$ & $59.67 \pm 2.028$ & $53.00 \pm 2.646$ & $57.33 \pm 0.882$ \\
\hline EE & $53.000 \pm 2.082$ & $58.67 \pm 2.186$ & $56.33 \pm 0.333$ & $59.00 \pm 4.00$ \\
\hline NDF & $46.333 \pm 1.333$ & $47.000 \pm 0.577$ & $44.67 \pm 1.764$ & $48.33 \pm 5.044$ \\
\hline ADF & $37.000 \pm 2.082$ & $42.333 \pm 3.383$ & $40.33 \pm 5.897$ & $45.67 \pm 6.386$ \\
\hline Cellulose & $34.672 \pm 1.202$ & $39.671 \pm 0.882$ & $42.00 \pm 2.082$ & $44.67 \pm 3.712$ \\
\hline
\end{tabular}


Table.8 Digestibility (\%) of various nutrients post calving for different groups

\begin{tabular}{|l|l|l|l|l|}
\hline Parameter & HEC & HECh & LEC & LECh \\
\hline DM & $50.00 \pm 2.517^{\text {ab }}$ & $59.333 \pm 3.383^{\mathrm{b}}$ & $45.667 \pm 1.856^{\mathrm{a}}$ & $48.333 \pm 2.333^{\mathrm{ab}}$ \\
\hline OM & $51.667 \pm 2.333^{\mathrm{a}}$ & $64.333 \pm 3.18^{\mathrm{b}}$ & $48.333 \pm 2.404^{\mathrm{a}}$ & $53.667 \pm 2.728^{\mathrm{a}}$ \\
\hline CP & $52.333 \pm 2.404^{\mathrm{a}}$ & $63.00 \pm 3.055^{\mathrm{b}}$ & $51.333 \pm 0.333^{\mathrm{a}}$ & $56.00 \pm 1.155^{\text {ab }}$ \\
\hline EE & $59.00 \pm 1.732$ & $65.667 \pm 1.764$ & $61.333 \pm 0.882$ & $65.00 \pm 1.528$ \\
\hline NDF & $47.00 \pm 2.082^{\mathrm{a}}$ & $55.333 \pm 1.202^{\mathrm{b}}$ & $46.00 \pm 1.528^{\mathrm{a}}$ & $53.667 \pm 1.764^{\mathrm{b}}$ \\
\hline ADF & $38.333 \pm 1.856^{\mathrm{a}}$ & $46.000 \pm 1.528^{\mathrm{bc}}$ & $41.667 \pm 1.764^{\mathrm{ab}}$ & $48.667 \pm 0.882^{\mathrm{c}}$ \\
\hline Cellulose & $38.00 \pm 1.732$ & $44.000 \pm 2.00$ & $39.667 \pm 1.202$ & $46.333 \pm 2.333$ \\
\hline
\end{tabular}

Different superscripts in row vary significantly at $5 \%$ level of significance

Table.9 Body weight around calving for different groups

\begin{tabular}{|c|c|c|c|c|c|}
\hline Month & HEC & HECh & LEC & LECh & SEM \\
\hline-1 & 534.0 & 538.3 & 537.5 & 528.0 & 2.34 \\
\hline 0 & 466.0 & 472.9 & 475.0 & 458.0 & 3.84 \\
\hline 1 & 428.0 & 451.4 & 440.0 & 440.0 & 4.78 \\
\hline 2 & 400.0 & 465.7 & 430.0 & 437.86 & 15.55 \\
\hline \multicolumn{6}{|c|}{ Loss in body weight } \\
\hline-1 to 0 & -68.0 & -65 & -62.50 & -70.0 & 6.7 \\
\hline 0 to 1 & -38.0 & -21.5 & -35.0 & -18.0 & 5.05 \\
\hline 1 to 2 & $-28.0^{b}$ & $14.3^{\mathrm{a}}$ & $-10.0^{a b}$ & $-2.14^{a}$ & 8.43 \\
\hline
\end{tabular}

Different superscripts in row vary significantly at 5\% level of significance

Table.10 Variation in BCS at different days (Mean \pm SE) Pre calving and Post calving for different groups

\begin{tabular}{|l|l|l|l|l|l|}
\hline No. of days & HEC & HECh & LEC & LECh & Average \\
\hline $\mathbf{- 2 1}$ & $3.5 \pm 0.08$ & $3.46 \pm 0.07$ & $3.4 \pm 0.06$ & $3.50 \pm 0.05$ & $3.48 \pm 0.69^{\mathrm{c}}$ \\
\hline $\mathbf{- 1 4}$ & $3.65 \pm 0.06$ & $3.68 \pm 0.07$ & $3.69 \pm 0.07$ & $3.58 \pm 0.06$ & $3.65 \pm 0.08^{\mathrm{de}}$ \\
\hline $\mathbf{- 7}$ & $3.75 \pm 0.08$ & $3.71 \pm 0.07$ & $3.75 \pm 0.03$ & $3.80 \pm 0.05$ & $3.75 \pm 0.07^{\mathrm{e}}$ \\
\hline $\mathbf{0}$ & $3.60 \pm 0.06$ & $3.50 \pm 0.05$ & $3.50 \pm 0.03$ & $3.55 \pm 0.05$ & $3.54 \pm 0.06^{\mathrm{cd}}$ \\
\hline $\mathbf{3 0}$ & $3.25 \pm 0.08$ & $3.18 \pm 0.07$ & $3.13 \pm 0.07$ & $3.20 \pm 0.05$ & $3.19 \pm 0.08^{\mathrm{b}}$ \\
\hline $\mathbf{6 0}$ & $2.95 \pm 0.05$ & $2.93 \pm 0.07$ & $2.88 \pm 0.07$ & $3.00 \pm 0.08$ & $2.94 \pm 0.08^{\mathrm{a}}$ \\
\hline $\mathbf{9 0}$ & $2.85 \pm 0.06$ & $2.86 \pm 0.07$ & $2.81 \pm 0.12$ & $2.85 \pm 0.10$ & $2.85 \pm 0.09^{\mathrm{a}}$ \\
\hline Average & $3.36 \pm 0.03$ & $3.33 \pm 0.02$ & $3.31 \pm 0.03$ & $3.36 \pm 0.03$ & $\begin{array}{l}\text { No. of Days } \times \text { Group } \\
\text { significant }(\mathrm{p}<0.05)\end{array}$ \\
\hline
\end{tabular}

Different superscripts in row vary significantly at $5 \%$ level of significance

Significant differences $(\mathrm{P}<0.05)$ in the values of body condition score (BCS) were found at different days during transition period irrespective of different groups (Table 10).
BCS was significantly improved $(\mathrm{P}<0.05)$ during precalving stage and then significantly decreased $(\mathrm{P}<0.05)$ during early and mid lactation upto 90 days post calving. This 
decrease during early lactation occurs due to utilization of cow's own body reserves for production of milk components (NRC 2001). For different groups irrespective of the number of days around calving, no significant difference was there in the values of BCS. These results suggested that change in BCS is not affected by RPC supplementation as told previously by Piepen brink and Overton (2003). Significant interaction $(\mathrm{P}<0.05)$ was found between number of days and different groups for BCS.

In conclusion, DMI was significantly higher in groups fed on high energy ration than groups fed on low energy ration. RPC supplementation before calving increased the body weight gain post calving. Body weight and BCS loss was less in RPC supplemented groups than control groups so RPC supplementation improves post calving body condition of cows. Feeding of RPC during transition period starting from $-21 \mathrm{~d}$ to $+10 \mathrm{~d}$ improved the intake and body weight gain of the high yielding dairy cows for both low and high energy rations.

\section{References}

Allen, M.S., and Mertens D R. 1988. Evaluating constraints on fiber digestion by rumen microbes. The Journal of Nutrition 118: 261-270.

AOAC. 2000. Official Method of Analysis $\left(17^{\text {th }}\right.$ ed.). Association of Official Analytical Chemists, Inc., Maryland, USA.

Atkins, K.B., Erdman R A, and Vandersall J H. 1988. Dietary choline effects of milk yield and duodenal choline flow in dairy cattle. J. Dairy Sci. 71: 109116.

Bertics, J., Sandra, Grummer, R R, Cadorniga-Valino Carlos and Stoddard Emily E. 1992. Effect of prepartum dry matter intake on liver triglyceride concentration and early lactation. J Dairy Sci 75:1914-1922.

Chung, Y.H., Cassidy T W, Girard I D, Cavassini P, and Varga G A. 2005. Effects of rumen protected choline and dry propylene glycol on feed intake and blood metabolites of Holstein dairy cows. J. Dairy Sci., 88(Suppl. 1): 61(Abstr.)

Dado, R.G., and Allen M S. 1995. Intake limitations, feeding behavior, and rumen function of cows challenged with rumen fill from dietary fiber or inert bulk. J. Dairy Sci.78: 118-133.

Edmonson, A.J., Lean I J, Weaver L D, Farver T, and Webster G. 1989. A body condition scoring chart for Holstein dairy cows. J. Dairy Sci.72: 68-78.

Erdman, R.A., and Sharma B K. 1991.Effect of Dietary Rumen-Protected Choline in Lactating Dairy Cows. J. Dairy Sci. 74: 1641-1647.

Grummer, R.R., 1993. Etiology of lipid related metabolic disorders in periparturient dairy cattle. Journal of Dairy Science 76: 3882-3896.

Grummer, R.R., 1995. Impact of changes in organic nutrient metabolism on feeding the transition dairy cow. J. Anim. Sci. 73: 2820- 2833

Guretzky, JNA., Carlson D B, Garret J E, Drackley J K. 2006. Lipid metabolite profiles and milk production for holstein and jersey cows fed rumen protected choline during the periparturient period. Journal of Dairy Science89: 188-200.

Hill, F.W., and Anderson D L. 1958. Comparison of metabolizable energy and productive energy determinations with growing chicks. Journal of Nutrition 64: 587-603.

Lima, F.S., SaFilho M F, Greco L F, Susca F, Magalhaes V M, and Santos J E P. 2007. Effects of feeding rumen- 
protected choline on metabolism and lactation. Journal of Dairy Science 90(Suppl. 1): 174.

Mertens, D.R., 1994. Using a mass action model of ruminal function to estimate the filling effect of forage NDF. In: Proc. Ivth Intl. Workshop on Modelling Nutrient Utilization in Farm Cows. p 27. Ministry of Agriculture, National Institute of Animal Science, Foulum, Denmark.

Mohsen, M.K., Gaafar H M A, Khalafalla M M, Shitta A A, Yousif A M. 2011. Effect of rumen protected choline supplementation on digestibility, rumen activity and milk yield in lactating Friesian cows. Journal of Animal Science 44: 13-20.
Oelrichs, W.A., Lucy M C, Kerley M S, and Spain J N. 2004. Feeding soybeans and rumen-protected choline to dairy cows during the periparturient period and early lactation. Effects on production and energy balance. J. Dairy Sci. 87(Suppl. 1): 344(Abstr.)

Piepenbrink, M.S., and Overton T R. 2003. Liver metabolism and production of cows fed increasing amounts of rumen-protected choline during the periparturient period. J. Dairy Sci. 86: 1722-1733.

Sharma, B.K., and Erdman R A. 1989. In vitro degradation of choline from selected feedstuffs and choline supplements. J. Dairy Science72: 2772-2776.

\section{How to cite this article:}

Devendra Kumar Gupta, R.S. Grewal, Simarjeet Kaur and Lamba, J.S. 2019. Effect of Prepartum Rumen Protected Choline Supplementation on Postpartum Nutrient Intake, Digestibility and Body Weight Changes in Crossbred Dairy Cows. Int.J.Curr.Microbiol.App.Sci. 8(05): 816-824. doi: https://doi.org/10.20546/ijcmas.2019.805.097 